\title{
PENINGKATAN PENGETAHUAN IBU HAMIL TENTANG PESAN INTI 1000 HPK DI MASA PANDEMI DENGAN MEDIA LEAFLET MELALUI APLIKASI WHATSAPP
}

\author{
Mira Meliyanti ${ }^{1)}$, Susi Selyani ${ }^{2)}$ \\ ${ }^{1)}{ }^{2)}$ Program Diploma Tiga Kebidanan, STIKES Dharma Husada Bandung, Bandung \\ mirazallea@gmail.com
}

\begin{abstract}
Abstrak
Manusia mengalami pertumbuhan dan perkembangan di sepanjang daur kehidupannya. Pertumbuhan terjadi melalui penambahan dan pembesaran, sedangkan perkembangan adalah proses meningkatnya fungsi sel, jaringan, dan organ tubuh dalam bentuk yang sangat kompleks. Pola kecepatan tumbuh kembang janin menjadi bayi baru lahir dalam bentuk lengkap dan utuh, kemudian berkembang menjadi manusia dewasa yang utuh dan mandiri. Seribu hari pertama kehidupan adalah periode seribu hari mulai sejak terjadinya konsepsi hingga anak berumur 2 tahun. Periode ini disebut periode emas (golden periode) atau disebut juga sebagai waktu yang kritis, yang jika tidak dimanfaatkan dengan baik akan terjadi kerusakan yang bersifat permanen (window of opportunity). Penelitian ini bertujuan untuk mengetahui peningkatan pengetahuan ibu tentang pesan inti 1000 HPK di Masa Pandemi dengan Media Leaflet dan Pemanfaatan Media WhatsApp di PMB Bidan R kabupaten bandung barat. Penelitian ini menggunakan one group pretest posttest. Sampel berjumlah 30 responden dengan sasaran ibu hamil trimester satu. Media yang di gunakan yaitu Leaflet dan metode yang digunakan yaitu ceramah. Analisis data menggunakan uji Wilcoxon dengan taraf signifikan 0,05 .
\end{abstract}

Kata Kunci : Ibu hamil primigravida, 1000 hari pertama kehidupan bayi, Leaflet, Pengetahuan.

\section{PENDAHUALUAN}

Indonesia pada saat ini mengalami masalah gizi ganda yaitu masalah kekurangan gizi dan kelebihan gizi. Beban gizi ganda atau Double Burden of Malnutrition (DBM) adalah suatu keadaan koneksistensi antara kekurangan gizi dan kelebihan gizi makronutrien maupun mikronutrien di sepanjang kehidupan pada populasi, masyarakat, keluarga dan bahkan individu yang sama ${ }^{1}$.

Menurut Kemenkes RI 2012, Angka Kematian Ibu (tinggi) 359/100.000 kelahiran hidup, angka kematian bayi (tinggi) 32/1.000 kelahiran, Bayi berat badan lahir rendah 13\%, Stunting (dibawah usia 5 tahun) 37\%. Di Kabupaten Bandung Barat pada tahun 2020,
Angka Kematian Ibu 123/100.000 kelahiran hidup dengan angka kematian bayi sebesar 3,9/1.000 kelahiran, prevalansi stunting 13,76\% (Dinkes KBB).

Sejak tahun 2012, pemerintah Indonesia mencanangkan Gerakan 1000 HPK (Hari Pertama Kehidupan. Masa 1000 HPK, yang bermula sejak saat konsepsi hingga anak berusia 2 tahun, yaitu 270 hari kehamilan dan 730 hari setelah lahir. Masa ini disebut periode emas karena merupakan masa paling kritis untuk memperbaiki perkembangan fisik dan kognitif anak. Status gizi ibu hamil dan ibu menyusui, status kesehatan dan asupan gizi yang baik merupakan faktor penting untuk pertumbuhan dan perkembangan fisik dan 
JURNAL SEHAT MASADA VOLUME XVI kognitif anak, menurunkan risiko kesakitan pada bayi dan ibu. Ibu hamil dengan status gizi kurang akan menyebabkan gangguan pertumbuhan janin, penyebab utama terjadinya bayi pendek (stunting) dan meningkatkan risiko obesitas dan penyakit degeneratif pada masa dewasa. Faktor lainnya adalah pengetahuan ibu yang kurang, pola asuh yang salah, sanitasi dan hygiene yang buruk dan rendahnya pelayanan kesehatan sejak bayi masih dalam kandungan ibu ${ }^{1}$.

Pendidikan Kesehatan pada Ibu Hamil "1000 Hari Pertama Kehidupan untuk Generasi yang lebih Baik" menawarkan jendela peluang yang sangat penting untuk membangun kesehatan jangka panjang. Gizi yang tepat selama periode kritis ini benar-benar penting dan menentukan generasi bangsa. Pesatnya pertumbuhan dan perkembangan selama kehamilan, menyusui dan anak usia dibawah 2 tahun diperlukan kebutuhan gizi tertentu selama setiap tahap sehingga diperlukan kesadaran pentingnya gizi. Oleh karena itu, sangat penting untuk memastikan setiap ibu dan anak mendapatkan akses dan pengetahuan gizi yang optimal selama 1000 hari pertama kehidupan.

Praktik Bidan Mandiri R merupakan praktik tempat pelayanan KIA yang terletak di wilayah Kabupaten Bandung Barat. Tidak sedikit ibuibu yang bersalin di bidan $\mathrm{R}$ mengalami perdarahan karena pada saat hamil mengabaikan anjuran bidan untuk meminum rutin zat besi karena kurangnya pengetahuan tentang pentingnya zat besi. Studi pendahuluan dilakukan kepada 10 responden yang berkunjung ke PMB bidan R, dimana dari 10 ibu, hanya 3 ibu yang mengetahui apa itu
NOMOR 1 Januari 2022

ISSN : 1979-2344 cakupan pesan inti 1000 HPK, dapat diperkirakan bahwa pengetahuan responden perlu ditingkatkan. Oleh karena itu peneliti tertarik untuk melakukan penelitian mengenai peningkatan pengetahuan ibu hamil tentang pesan inti 1000 HPK di masa pandemik dengan media leaflet yang disebarkan kepada ibu hamil yang memeriksakan kehamilan di Praktik Bidan Mandiri R melalui whatsapp.

Berdasarkan latar belakang masalah di atas maka dapat diambil rumus masalah yaitu “ Apakah ada pengaruh upaya peningkatan pengetahuan ibu hamil tentang pesan inti 1.000 HPK dimasa pandemik dengan media leaflet dan pemanfaatan media whatsapp?".

\section{METODOLOGI}

Jenis Penelitian adalah penelitian kuantitatif untuk mengetahui tingkat pengetahuan ibu tentang pesan inti 1000 HPK di PMB Bidan R Kota Bandung Barat.

Penelitian dilakukan pada bulan April

- Mei 2021. Rancangan penelitian yaitu menggunakan one group pretest posttestdesign. Rancangan jenis ini hanya menggunakan satu kelompok subyek, pengukuran dilakukan sebelum dan sesudah perlakuan.

Populasi dalam penelitian ini adalah ibu hamil trimester I yang bertempat tinggal disekitar wilayah kerja PMB Bidan $\mathrm{R}$ sebanyak 150 orang. Sampel penelitian berjumlah 30 ibu hamil. Pemilihan sampel menggunakan teknik probability sampling yang memenuhi kriteria inklusi sebagai berikut :

- Bisa membaca dan menulis 
JURNAL SEHAT MASADA VOLUME XVI

- Tidak sedang menderita penyakit kronis

- Menyatakan bersedia menjadi responden

\section{HASIL DAN PEMBAHASAN}

A. Hasil

Tabel 1

Distribusi frekuensi pengetahuan ibu sebelum diberikan pengetahuan tentang pesan inti 1000 HPK dengan media leaflet di wilayah kerja PMB bidan R

\begin{tabular}{cccc}
\hline No & Kategori & f & $\%$ \\
\hline 1 & Baik & 5 & 16 \\
2 & Cukup & 17 & 56,7 \\
3 & Kurang & 8 & 26,7 \\
\hline & Total & 30 & 100,0 \\
\hline
\end{tabular}

Pengetahuan responden sebelum diberi pengetahuan tentang pesan inti 1000 HPK , lebih banyak (56.7\%) kategori cukup.

Tabel 2

Distribusi frekuensi pengetahuan ibu setelah diberikan pengetahuan tentang pesan inti 1000 HPK dengan media leaflet di wilayah kerja PMB bidan $R$

\begin{tabular}{cccc}
\hline No & Kategori & f & $\%$ \\
\hline 1 & Baik & 19 & 63,3 \\
2 & Cukup & 11 & 36,7 \\
3 & Kurang & 0 & 0 \\
\hline & Total & 30 & 100,0 \\
\hline
\end{tabular}

Pengetahuan responden setelah diberi pengetahuan tentang pesan inti 1000 HPK , lebih banyak (56.7\%) kategori Baik

Tabel 3

Pengetahuan Ibu Sebelum dan Sesudah Diberikan Pengetahuan tentang Pesan Inti 1000 HPK dengan Media Leaflet di Wilayah Kerja PMB Bidan $\mathbf{R}$

\begin{tabular}{cccc}
\hline Pengatahuan & $\mathrm{N}$ & Mean & Standar Deviation \\
\hline Sebelum & 30 & 13.30 & 3.229 \\
\hline Sesudah & 30 & 17.60 & 4.407 \\
\hline
\end{tabular}

Rata-rata skor pengetahuan pada responden yang mendapat intervensi atau pengetahuan tentang pesan inti 1000 HPK denagn media leaflet untu hasil pre-test yaitu sebesar 13,30. Sedangkan untuk hasil post - test mengalami peningkatan yang signifikan yaitu menjadi 17,60. Selisih untuk rata-rata skor nilai pretest dan postest yaitu sebesar 4,3. hasil uji beda 0,000 atau $<0,005$

\section{B. Pembahasan}

\section{1) Pengetahuan Sebelum dan Sesudah}

Terdapat peningkatan yang bermakna antara pretest dan posttest pengetahuan ibu setelah diberikan leaflet ibu hamil selama covid-19.

Pengetahuan adalah aspek yang paling dasar dalam taksonomi Bloom. Pengetahuan hafalan yang perlu diingat seperti rumus, batasan definisi, istilah pasal dalam undangundang, nama dan tokoh, nama-nama kota dan lain-lain. Hafal menjadi prasyarat bagi pemahaman, misalnya hafal suatu rumus maka kita akan paham bagaimana menggunakan rumus tersebut atau hafatl kata-kata akan memudahkan membuat kalimat.

Seseorang mungkin paham tentang 9 pesan inti pada 1000 HPK yang diperlukan untuk kesehatan tetapi tidak pernah mengaplikasikan pengetahuan kedalam kehidupan sehari-hari. Menurut Notoatmodjo, 
JURNAL SEHAT MASADA

adapun factor yang mempengaruhi

pengetahuan salah satunya yaitu media. Media adalah alat atau sarana komunikasi untuk perantara atau penghubung. Media terbagi menjadi media cetak, elektronik, film, massa, pendidikan dan periklanan, media yang digunakan pada penelitian ini adalah leaflet yang disusun oleh peneliti sendiri.

Keunggulan dari leaflet yang dibuat oleh peneliti adalah materi yang terdapat dalam leaflet lebih lengkap, lebih spesifik tentang 9 pesan inti pada 1000 HPK yang dibutuhkan selama kehamilan apalagi di Era Covid 19 sehingga harapannya dengan kehamilan yang sehat makan angka stunting akan berkurang.

\section{Uji Beda Pengetahuan Sebelum dan Sesudah}

Berdasarkan nilai rata-rata pengetahuan ibu saat pretest yaitu sebesar $56,7 \%$ dari 30 soal tentang 9 pesan inti 1000 Hari Pertama Kehidupan yang diberikan sebelum penkes kepada 30 responden. Diketahui bahwa hasil pre test sebelum diberikan penkes, nilai frekuensi baik 5 orang, 17 orang cukup, dan 8 oarng kurang. Ini menunjukaan bahwa pengetahuan ibu tentang 9 pesan inti 1000 Hari Pertama Kehidupan sebelum diberikan penkes sudah cukup tetapi masih ada beberapa ibu yang tingkat pengetahuannya masih kurang.

Tingginya angka kejadian bayi stunting dan ibu hamil anemia di PMB Bidan R salah satunya dipengaruhi oleh kurangnya pengetahuan ibu terkiat 9 pesan inti 1000 Hari Pertama Kehidupan termasuk didalamnya terdapat gizi untuk bayi, imunasi wajib, gizi bagi ibu hamil, mengkonsumsi tablet tambah
NOMOR 1 Januari 2022 ISSN : 1979-2344 darah atau tablet $\mathrm{Fe}$ yang di berikan oleh bidan, MP-ASI, asi eksklusif, dan pemeriksaan kehamilan. Pengetahuan ibu yang rendah juga menjadi hambatan untuk menurunkan angka kejadian bayi stunting dan ibu hamil dengan anemia, penetahuan yang rendah cenderung memiliki pola hidup atau kebiasaan yang buruk.

Berdasarkan penkes dan postest yang telah dilakukan, didapatkan hasil rata - rata nilai pengetahuan saat pretest yaitu sebesar 13,30 dan hasil postest yaitu sebesar 17,60 sehingga terdapat selisih skor 4,3. Rata -rata nilai saat pretest dan postest yang meningkat menunjukkan bahwa manfaat dari pemberian pendidikan kesehatan 9 pesan inti 1000 Hari Pertama Kehidupan dengan media leaflet berhasil.

Pada penelitian ini leaflet merupakan salah satu media yang dipilih dari sekian banyak media yang ada. Digunanakannya medoa leaflet sebagai media karean ibu akan cenderung lebih mudah untuk memahami tentang informasi karena informasi yang tercantum dalam leaflet tergolong mudah dan dapat menyesuaikan belajar mandiri, selain itu ibu juga dapat melihat dan mempelajari isisnya saat santai.dengan media leaflet ini informasi yang disampaikan lebih banyak dan lebih mudah diterima oleh ibu.selain itu juga leaflet dapat disimpan dan bisa dibaca sewaktuwaktu.

Setelah dilakukan penelitian dengan hasil yang di dapatkan dari pemberian materi 9 pesan inti 1000 Hari Pertama Kehidupan dengan media leaflet dan dilakukannya pretest dan postest dari 30 responden mengalami 
JURNAL SEHAT MASADA VOLUME XVI peningkatan nilai pengetahuan . Peningkatan pengetahuan 30 responden ini karena materi yang disampaikan merupakan materi yang sesuai dengan sasaran dan media yang digunakan yaitu leaflet yang berisi materi beserta gambar yang memudahkan responden untuk memahami materi.

Sehingga dapat disimpulkan bahwa pendidikan kesehatan 9 pesan inti 1000 Hari Pertama Kehidupan dengan media leaflet memberikan pengaruh yang signifikan terhadap peningkatan pengetahuan ibu yaitu 0,000 atau $<0,005$, dengan nilai skor pretest yaitu 13,30 dan postest sebesar 17,60 dengan selisih skor sebesar 4,3.

\section{KESIMPULAN}

Media leaflet dan pemanfaatan media whatsapp efektif dalam upaya peningkatan pengetahuan ibu hamil tentang pesan inti 1.000 HPK dimasa pandemic. Penelitian lanjutan dapat dilakukan pada populasi yang berbeda dan dapat menggunakan media yang berbeda seperti brosur, pamphlet dan video edukasi yang dapat memanfaatkan aplikasi whatsapp.

\section{DAFTAR PUSTAKA}

1. American Association of Critical-Care Nurses (AACN). 2013. Nurse Competencies of Concern to Patients, Clinical Units and Systems. Retrieved from

http://www.aacn.org/wd/certifications/cont ent/synpract2.pcms?menu.

2. Andarmoyo, Sulistyo. 2012. Keperawatan Keluarga Konsep Teori, Proses dan Praktik Keperawatan. Yogyakarta: Graha Ilmu.
NOMOR 1 Januari 2022

ISSN : 1979-2344

3. Direktorat Bina Pelayanan Keperawatan Direktorat Jendral Bina Pelayanan Medik Departemen Kesehatan RI. 2006. Pedoman Penyelenggaraan Jenjang Karir Profesional Perawat. Jakarta: UUD RI.

4. Hughes, 2005. Elaine. Nurses' perceptions of continuing professional development. Nursing Standart. Vol 19 No. 43, 41-49.

5. Istirochah, I. and Santoso, A., 2017. Gambaran Pelaksanaan Praktik Keperawatan Profesional Perawat Klinik III berdasarkan Kewenangan Klinis di Instalasi Rawat Inap Rsup Dr. Kariadi Semarang (Doctoral dissertation, Diponegoro University).

6. Kemenkes, R. 2017. Situasi Tenaga Keperawatan. Jakarta: InfoData

7. Kolibu, F. K., Hariyanto, T., \& Pusparahaju, A. 2014. Pengembangan Model Jenjang Karir Perawat Klinis di Unit Rawat Inap Rumah Sakit. Jurnal Kedokteran Brawijaya, 28(1), 59-64.

8. Yvonne ten Hoeve, Gerard Jansen \& Petrie Roodbol. 2013. The Nursing Profession: Public Image, Self-Concept and Professionalidentity. A Discussion Paper. JAN: Discussion Paper. 296-309 